\title{
The importance of non-forest tree stand features for protection of the Syrian Woodpecker Dendrocopos syriacus in agricultural landscape: a case study from South- Eastern Poland
}

\author{
Jerzy Michalczuk (1)
}

Received: 12 October 2019/Accepted: 4 May 2020/Published online: 13 May 2020

(C) The Author(s) 2020, corrected publication 2020

\begin{abstract}
Non-forest tree stands are important habitats for many species of birds in the agricultural landscape. They are also the main habitat of the Syrian Woodpecker Dendrocopos syriacus, whose numbers have been decreasing in recent years in some parts of Europe. Recognition of the habitat requirements of this species may help better planning of its protection in the context of the treed agricultural landscapes. During this study, the habitat preferences of the Syrian Woodpecker were determined in the agricultural landscape of South-Eastern Poland. A set of 12 habitat parameters of tree stands located in the breeding territories of the Syrian Woodpecker $(n=122)$ and in randomly chosen control areas $(n=122)$ located outside the range of the breeding territories of this species were characterized. The number and species diversity of trees was significantly higher in stands located in Syrian Woodpecker territories than in the random control areas. Stands occupied by breeding pairs also had trees of worse health condition and a larger proportion of fruit trees. The model best explaining the probability of the occurrence of the species indicates that the Syrian Woodpecker requires mainly the presence of tree stands with a greater species diversity of trees, as well as tree stands in
\end{abstract}

J. Michalczuk ( $\square)$

Department of Nature Conservation and Landscape

Ecology, University of Rzeszów, Zelwerowicza 4,

35-601 Rzeszow, Poland

e-mail: jurmich@univ.rzeszow.pl worse health condition. When planning the protection of this species' habitats in the agricultural landscape, the characteristics of non-forest tree stands noted above should be taken into account.

Keywords Rural landscape · Semi-open landscape · Human-settlements tree stands $\cdot$ Synanthropic environments $\cdot$ Habitat conservation $\cdot$ Bird protection planning

\section{Introduction}

The presence of various types of tree stands in the agricultural landscape is important for the occurrence of many bird species in Europe (e.g. Berg 2002; Domokos and Domokos 2016; Dorresteijn et al. 2018). Such habitats may also be valuable for woodpeckers whose populations are concentrated mainly in small woodlots or non-forest tree stands. Such species include, for example, the European Green Woodpecker Picus viridis and the Wryneck Jynx torquilla (Spitznagel 1990; Glue and Boswell 1994; Michalczuk et al. 2018). In the semi-open landscape, Great Spotted Woodpecker Dendrocopos major is also commonly found, often occurring in parks, but additionally inhabiting orchards, tree-lined avenues and clumps of trees (Glue and Boswell 1994; Hebda 2009; Michalczuk and Michalczuk 2016c). Such tree 
stands in the agricultural landscape are preferred primarily by the Syrian Woodpecker Dendrocpos syriacus (hereafter SW, Michalczuk and Michalczuk 2016b; Michalczuk et al. 2018), a species of the EU importance, enlisted in Annex I of the Birds Directive (Directive 2009). This woodpecker species is highly synanthropic, as it can nest in the immediate surroundings of humans, e.g. on busy roads or even in the vicinity of residential buildings (Michalczuk and Michalczuk 2016b).

In previous studies on the preferences of the SW, various macro-habitat parameters were analysed, such as the degree of the use of particular types of trees or their share within the bird's territories (Michalczuk and Michalczuk 2011, 2016a; Kajtoch and Figarski 2017). Some research suggests that this species may occupy larger areas of tree stands (Ciach and Fröhlich 2013), which usually include gardens and orchards, but also other loosely treed woodlots in the agricultural landscape (Michalczuk and Michalczuk 2011, 2016c; Kajtoch and Figarski 2017; Figarski and Kajtoch 2018). The parameters of the trees occurring in the habitats occupied by this species have been assessed only occasionally, during the research on the SW (Michalczuk and Michalczuk 2016b; Figarski and Kajtoch 2018). They indicate that, for example, larger dimensions of tree trunks recorded in the birds' territories or used for nesting may be favoured by SW (Aghanajafizadeh et al. 2011; Michalczuk and Michalczuk 2016b; Figarski and Kajtoch 2018). When selecting sites for nest building, the poor health condition may also increase trees suitability for this species, as a wood softener, facilitating cavity excavation. In the agricultural landscape, this is closely related to the frequent use by these woodpeckers of weakened, sick or dying fruit trees (Michalczuk and Michalczuk 2016b). The preference of fruit trees is amplified by the fact that fruits and seeds are an important part of the diet of both adult birds and their nestlings (Stevanović 1960; Szlivka 1962; Winkler 1972; 1973; Mitjaj 1986; Michalczuk and Michalczuk 2017).

Although the habitats of SW are still widely available in the agricultural landscape, they are often devastated or even erased (e.g. Michalczuk and Michalczuk 2015). This problem especially concerns old fruit orchards, which, during the last two decades, have been undergoing extensive felling, what is commonly observed in South-Eastern Poland
(Michalczuk and Michalczuk 2015). Such processes might be considered an important culprit responsible for the decline of SW in that region (Michalczuk et al. 2011; Michalczuk and Michalczuk 2015) and possibly also in other regions of Europe (e.g. Hristov and Petkov 2013; Spasov et al. 2017).

Considering the observed negative trend of SW's European population, it is necessary to further studies on ecological interactions between the woodpecker and the quality of its habitat. Numerous habitat factors can influence this species occurrence. Some studies indicate, that for the presence of this species in the urban environment, the presence of a larger tree stands with a greater number of trees may be important (Ciach and Fröhlich 2013). Other authors (Figarski and Kajtoch 2018) indicated, that the presence of trees with larger trunk sizes and with bigger basal area is crucial. In agricultural landscape the presence of trees in a poor health condition, which are used by birds for hole excavation, could be very important (Michalczuk and Michalczuk 2016a, 2020a, b). The purpose of this study was to determine the habitat requirements of the species that may help better planning its protection in the context of the treed agricultural landscapes. In order to determine specific characteristics of stands and trees preferred by SW, a set of selected biological and biometric parameters of the woodpecker's habitat stands have been compared to the characteristics of the peer, but unoccupied stands.

\section{Study area and methods}

The study area (ca. $305 \mathrm{~km}^{2}$ ) was situated in the agricultural landscape of SE Poland $\left(50^{\circ} 28^{\prime} \mathrm{N}\right.$, $23^{\circ} 40^{\prime}$ E, Fig. 1), near Tomaszów Lubelski, $10 \mathrm{~km}$ west from the Ukrainian border, in western part of the Volhynian Upland (Kondracki 2000). Due to very fertile soils (Bański 2010), arable grounds constitute ca. $75 \%$ of the area. Meadows cover about $15 \%$ and occur mainly in the valleys of small rivers. Highly fragmented forests, occupying $3.5 \%$ of the study area, are mostly composed of hornbeam Carpinus betulus and oak Quercus robur, Q. petraea, in the eastern part of the area, and Scots pine Pinus sylvestris in the western part (BDL 2016; Michalczuk et al. 2018). The non-forest groves, tree lines and scattered trees, and orchards, accompanying build up areas, contribute to $3 \%$ of the area. They mainly consist of gardens or 


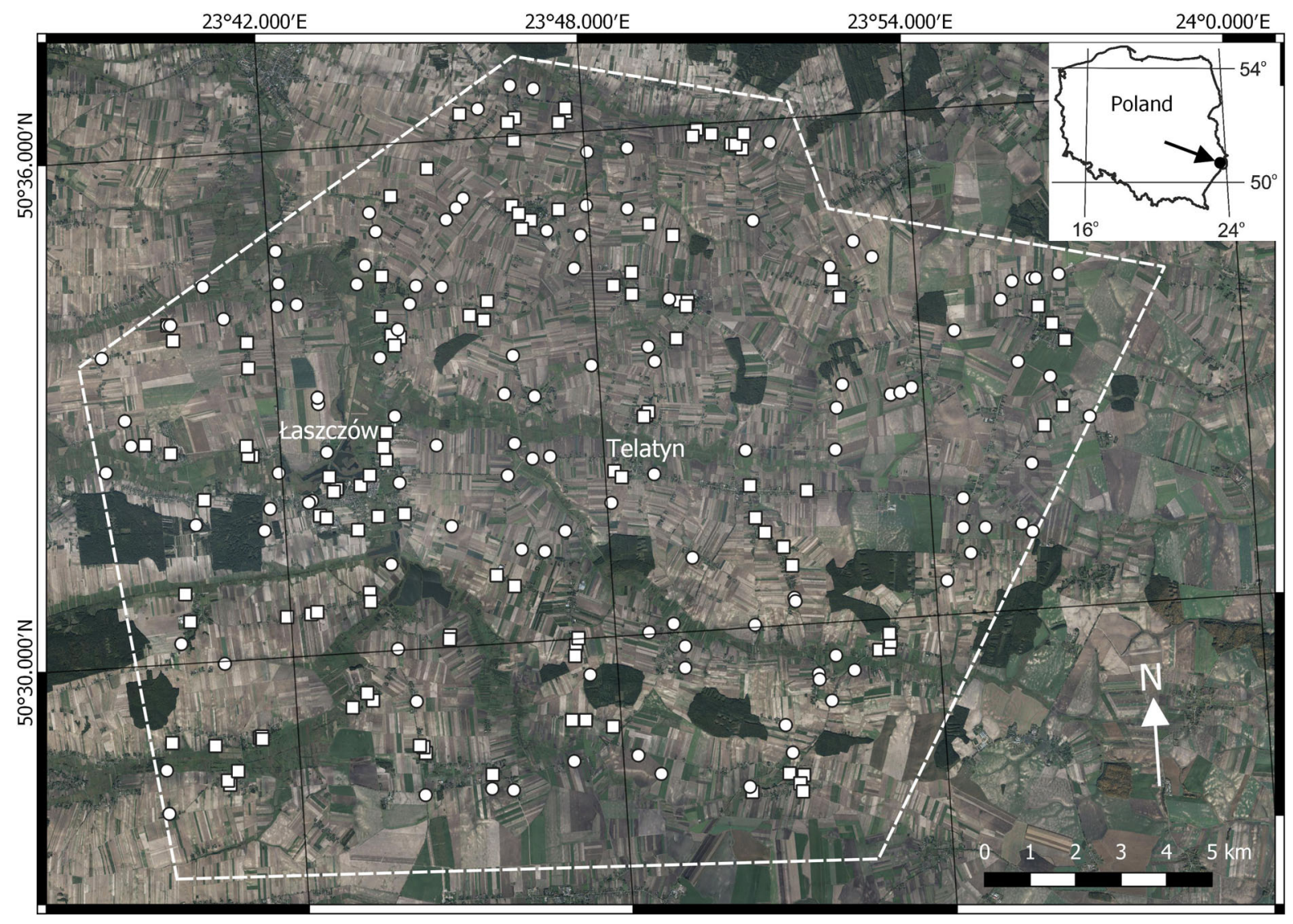

Fig. 1 Distribution of randomly selected tree stand plots inside and outside breeding territories of the Syrian Woodpecker in the study area (map is based on www.geoportal.gov.pl).

orchards, dominated by apple trees Malus domestica, sweet cherry trees Prunus cerasus, plum trees Prunus spp., and walnuts Juglans regia. Willows Salix spp., poplars Populus spp., maples Acer spp. and ashes Fraxinus spp. are the main road-side species, in-field tree lines, single trees and parks. In addition, there are small lots of planted spruce Picea spp., European Larch Larix decidua and Scot pine (Michalczuk and Michalczuk 2016a, b; Michalczuk et al. 2018).

\section{Detection of breeding territories}

The SW breeding territories were determined with voice stimulation (for details see Michalczuk and Michalczuk 2006a, b; Michalczuk et al. 2011; Michalczuk and Michalczuk 2016a, b; Michalczuk et al. 2018) in 2007-2009. The search was conducted in the
Denotations: dashed line-study area border, squares-tree stands inside breeding territories, dots-tree stands outside breeding territories

non-forest tree settlements located in the villages and in in-field woodlots. Counts were carried out mainly along roads, with simulation points every $200-400 \mathrm{~m}$. As a simulation, a 5-min sequence of Syrian Woodpecker calls and drumming was played. The sites of bird spotting sites were marked on a topographic map at a scale of $1: 10,000$. In order to determine the territories, at least the entire study area has been visited at least six times each breeding season from March to July. A breeding territory was determined when the birds presence in the given area had been confirmed at least three times, including at least one observation of a pair of birds or an alternating male and female (for details see Michalczuk and Michalczuk 2006a, b, 2015, 2016a, b). The territories of particular woodpecker breeding pairs were determined on the aggregated maps. Boundaries of individual territories were determined by connecting the farthest 
external points, where the birds of a given breeding pair were observed and marked on the map (for details see Michalczuk and Michalczuk 2006a, b, 2015, 2016b).

\section{Selection and description of tree stands}

Tree stands occupied by SW were evaluated in all 122 breeding territories. In order to do this, circular plots, $R=20 \mathrm{~m}$ (0.125 ha), were randomly set, one in each breeding territory (for details see Michalczuk and Michalczuk 2016b). As it was confirmed in numerous previous studies (e.g. Michalczuk \& Michalczuk 2016b, Figarski and Kajtoch 2018), such a big area allows to accurately describe many of tree stands measurements. For this purpose, on the map (in 1:10,000 scale) with outline territories range we outlined a network of points. To do this, we have drawn vertical and horizontal lines in regular $0.5 \mathrm{~cm}$ distance. Crossings of these lines marked the points on the territory map. The lines were numbered to choose tree points to assess. Then we randomized numbers of horizontal and vertical lines using so called "golden numbers" (Zieliński 1972). The cross of these two random lines gives a random point which we were looking for in fields. Most of the sites had no trees, as they were located in fields or meadows, which occupy over $80 \%$ of the study area. In such cases new points were selected, until a wooded area was within the range. If a sampling plot had trees with a diameter of at least $16 \mathrm{~cm}$, they were ranked as a potential territory tree plot. If not, a new point was chosen by this iterative method. Trees of trunk diameter size equal to and greater than $16 \mathrm{~cm}$ are potentially suitable for nest excavation by the SW (own observations), so their occurrence can determine its presence in environment. In this way were excluded from the analyse shrubs and woodlots with too tiny trees, that can't inhabited by woodpeckers (Michalczuk and Michalczuk 2016b).

The tree stands potentially occupied by the woodpecker, were also described. For this purpose, in the whole study area without breeding territories, 122 circular control plots with a radius of $20 \mathrm{~m}$ were randomly selected. These plots were determined by method analogous as using for selection of the tree stands in breeding territories (for details see description above). After plot selection, the measurements of trees were made (Table 1). This evaluation was done after breeding season. In the first step, trees were classified by species. Afterwards, the tree trunks were callipered at $1.3 \mathrm{~m}$ above the ground (DBH). The health condition of trees was assessed with a fourpoint scale: 1 - healthy, 2 - weakened, 3 - dying and 4 - dead (Table 1, Michalczuk and Michalczuk 2016b). Each stand has been characterized with twelve parameters: the Shannon-Wiener species diversity index $\left(\mathrm{H}^{\prime}\right.$, Krebs 2014), number of trees, share (percentage) of fruit trees, number of trees in three trunk diameter ranges: between 16 and 40 , between 40 and 60 and greater than $60 \mathrm{~cm}$, average tree diameter and average tree health condition. Additionally, the number of trees in four health categories was specified (Table 1).

\section{Statistical analysis}

Due to the nonparametric distribution of the independent variables, the differences between individual habitat parameters between occupied and unoccupied territories by woodpeckers were evaluated using the Mann-Whitney $U$ test. In order to describe the dependence of the woodpecker on habitat parameters, multivariate logistic regression was used (Hosmer and Lemeshow 1989), because of the dichotomous distribution of the dependent variable (tree stand areas occupied and unoccupied by breeding pairs) was found. Spearman's correlation was used to check possible collinearity and then to eliminate the interdependence among the independent variables for which statistical differences were found. In this way, variables with a correlation coefficient value of Rho $>0.50$ were excluded from the analysis and only four were left for modelling: 1 - species diversity of trees $\left(\mathrm{H}^{\prime}\right), 2$ - total number of trees, 3 - share of fruit trees and 4 - average condition of tree health. Then, from the set of many models explaining the dependent variable containing the selected 4 independent variables, the optimal model was chosen using the Akaike information criterion (AIC; Burnham and Anderson 2002). For this purpose, the obtained models were ranked according to the increasing absolute value of AIC. Then, differences in the AIC criteria $(\triangle \mathrm{AIC})$ were calculated for each of the models, obtained after referencing them to the best model, i.e. the one with the lowest information criterion $\left(\mathrm{AIC}_{\mathrm{min}}\right)$. It was assumed (after Burnham and Anderson 2002) that a 
Table 1 Habitat parameters of the tree stands assessed during the study and included in the analysis

\begin{tabular}{|c|c|c|}
\hline Tree stand characteristic & Abbreviation & Description of the tree stand characteristic within the circular area \\
\hline Average trunk diameter & $\mathrm{DBH}$ & Average diameter of trees (diameter at breast height measured in $\mathrm{cm}$ ) \\
\hline Total number of trees & Total trees & Number of trees with a diameter $>16 \mathrm{~cm}$ \\
\hline $\begin{array}{l}\text { Number of trees with thin } \\
\text { trunks }\end{array}$ & Trees $16-40$ & Number of trees with a trunk diameter of $16-40 \mathrm{~cm}$ \\
\hline $\begin{array}{l}\text { Number of trees with } \\
\text { medium-sized trunks }\end{array}$ & Trees $41-60$ & Number of trees with a diameter of $41-60 \mathrm{~cm}$ \\
\hline $\begin{array}{l}\text { Number of trees with large } \\
\text { trunks }\end{array}$ & Trees $>60$ & Number of trees with a diameter $>60 \mathrm{~cm}$ \\
\hline Species diversity & Diversity & $\begin{array}{l}\text { Shannon-Wiener index }\left(\mathrm{H}^{\prime}\right) \text { of tree species diversity calculated on the basis of the } \\
\text { number of individual species }\end{array}$ \\
\hline Healthy trees & Healthy & Number of trees in good health (1 in a 4-point health scale) \\
\hline Weakened trees & Weakened & Number of weakened trees ( 2 in a 4-point health scale) \\
\hline Dying trees & Dying & Number of dying trees ( 3 in a 4-point health scale) \\
\hline Dead trees & Dead & Number of dead trees (4 in a 4-point health scale) \\
\hline $\begin{array}{l}\text { Average health condition of } \\
\text { the trees }\end{array}$ & Condition & $\begin{array}{l}\text { Mean value of tree condition calculated on the basis of the assessment of individual } \\
\text { trees on a four-point scale }\end{array}$ \\
\hline Share of fruit trees & Fruit trees & $\begin{array}{l}\text { Share }(\%) \text { of fruit trees (Apple, Pear, Plum, Cherry, Sweet Cherry, Walnut, Apricot, } \\
\text { Peach trees) among all trees recorded }\end{array}$ \\
\hline
\end{tabular}

The assessment of the specified tree stand parameters was made on the basis of the average values calculated for all trees with a trunk diameter equal to or greater than $16 \mathrm{~cm}$ growing in a circular area with a radius of $20 \mathrm{~m}$ (for details see methods)

delta AIC value $<2$ indicates the best models, whereas a delta AIC value of $>10$ indicates the lack of support for choosing such a model. Additionally, the relative reliability of the model was normalized by calculating Akaike weights (w). They were used to assess the relative advantage of the best (most weight) model over the other models. Finally, the whole sets of models were used for model averaging to check which environmental parameters have the major contributions to the prediction of birds' presence which referred to each variable criticality (Burnham and Anderson 2002). All statistical differences at a level of less than 0.05 were determined to be significant. The statistical analysis was performed using StatisticaSoft 13.1 Pl. and R package (R Development Core Team 2020).

\section{Results}

The population of Syrian Woodpecker in the study area was estimated in 2007-2009 respectively at 44, 42 and 36 pairs. Its density ranged from 1.18 to 1.44 breeding pairs per $10 \mathrm{~km}^{2}$ of the entire study area.

Out of all twelve analysed habitat parameters, statistical differences were found only for seven between stands that were occupied and unoccupied by the SW (Table 2). The tree stands occupied by the birds were characterized by an average higher number of trees compared to unoccupied stands. These differences were dictated mainly by the greater numbers of trees with trunk diameters in the range of $16-40 \mathrm{~cm}$ in the birds' territories. Many more sick and dying trees were also found in woodpecker occupied areas, which influenced the average worse condition of tree stands recorded within their breeding territories. Tree stands inhabited by woodpeckers were also characterized by a greater species diversity of trees and a greater share of fruit trees (Table 2).

The models best explaining the presence of woodpeckers compared to areas unoccupied by the species $($ Aic $<2)$ include four variables: diversity, health condition, number of trees and share of fruit trees (Table 3). The best models describing presence include the variable of diversity and tree health condition (Table 4). These were the habitat parameters that best explained the probability of the occurrence of SW (Table 5). The parameters in the second model also included the number of trees and in the third-the share of fruit trees (Table 4). 
Table 2 Comparison of the habitat parameters of tree stands in territories occupied and unoccupied by Syrian Woodpeckers
Mean values are given $\pm \mathrm{SD}$. Variables and abbreviations are described in Table 1. Parameters with statistical differences are in bold

\begin{tabular}{lcccc}
\hline Variables & Inside territories & Outside territories & Mann-Whitney $U$ test & $p$ \\
\hline Diversity & $\mathbf{0 . 9 8} \pm \mathbf{0 . 7 8}$ & $\mathbf{0 . 6 4} \pm \mathbf{0 . 7 6}$ & $\mathbf{3 . 3 1}$ & $\mathbf{0 . 0 0 1}$ \\
DBH & $35.9 \pm 16.7$ & $38.9 \pm 19.7$ & -0.89 & 0.371 \\
Trees $16-40$ & $\mathbf{4 . 1} \pm \mathbf{3 . 8}$ & $\mathbf{3 . 3} \pm \mathbf{3 . 7}$ & $\mathbf{2 . 3 4}$ & $\mathbf{0 . 0 1 9}$ \\
Trees $41-60$ & $1.1 \pm 1.4$ & $0.9 \pm 1.3$ & 1.04 & 0.300 \\
Trees $>60$ & $0.5 \pm 1.0$ & $0.4 \pm 1.0$ & -0.17 & 0.862 \\
Total number of trees & $\mathbf{5 . 7} \pm \mathbf{4 . 2}$ & $\mathbf{4 . 6} \pm \mathbf{4 . 0}$ & $\mathbf{2 . 7 4}$ & $\mathbf{0 . 0 0 6}$ \\
Healthy & $1.5 \pm 2.2$ & $1.6 \pm 2.6$ & -1.43 & 0.152 \\
Weakened & $\mathbf{3 . 1} \pm \mathbf{2 . 8}$ & $\mathbf{2 . 4} \pm \mathbf{2 . 3}$ & $\mathbf{2 . 0 5}$ & $\mathbf{0 . 0 4 1}$ \\
Dying & $\mathbf{1 . 0} \pm \mathbf{1 . 8}$ & $\mathbf{0 . 6} \pm \mathbf{1 . 1}$ & $\mathbf{2 . 1 2}$ & $\mathbf{0 . 0 3 4}$ \\
Dead & $0.1 \pm 0.3$ & $0.0 \pm 0.2$ & 0.67 & 0.504 \\
Condition & $\mathbf{2 . 4 9} \pm \mathbf{0 . 9 2}$ & $\mathbf{2 . 1 3} \pm \mathbf{0 . 8 7}$ & $\mathbf{3 . 1 0}$ & $\mathbf{0 . 0 0 2}$ \\
Fruit trees & $\mathbf{3 5 . 3} \pm \mathbf{3 8 . 4}$ & $\mathbf{2 4 . 7} \pm \mathbf{3 8 . 3}$ & $\mathbf{2 . 5 2}$ & $\mathbf{0 . 0 1 2}$ \\
\hline & & & &
\end{tabular}

Table 3 Spearman rank correlations of the habitat parameters that were found to have statistical differences

\begin{tabular}{|c|c|c|c|c|c|c|c|}
\hline Variables & $\begin{array}{l}\text { Trees } \\
16-40\end{array}$ & Weakened & Dying & Diversity & Total trees & Condition & Fruit trees \\
\hline Trees & 1.000 & 0.523 & 0.365 & 0.431 & 0.830 & 0.050 & 0.188 \\
\hline $16-40$ & $(0.000)$ & $(0.000)$ & $(0.000)$ & $(0.000)$ & $(0.000)$ & $(0.435)$ & $(0.003)$ \\
\hline Weakened & & $\begin{array}{l}1.000 \\
(0.000)\end{array}$ & $\begin{array}{l}0.205 \\
(0.001)\end{array}$ & $\begin{array}{l}0.404 \\
(0.000)\end{array}$ & $\begin{array}{l}0.734 \\
(0.000)\end{array}$ & $\begin{array}{l}0.225 \\
(0.000)\end{array}$ & $\begin{array}{l}0.108 \\
(0.092)\end{array}$ \\
\hline Dying & & & $\begin{array}{l}1.000 \\
(0.000)\end{array}$ & $\begin{array}{l}0.341 \\
(0.000)\end{array}$ & $\begin{array}{l}0.401 \\
(0.000)\end{array}$ & $\begin{array}{l}0.655 \\
(0.000)\end{array}$ & $\begin{array}{l}0.305 \\
(0.001)\end{array}$ \\
\hline Diversity & & & & $\begin{array}{l}1.000 \\
(0.000)\end{array}$ & $\begin{array}{l}0.488 \\
(0.000)\end{array}$ & $\begin{array}{l}0.210 \\
(0.001)\end{array}$ & $\begin{array}{l}0.410 \\
(0.001)\end{array}$ \\
\hline Total trees & & & & & $\begin{array}{l}1.000 \\
(0.000)\end{array}$ & $\begin{array}{l}0.103 \\
(0.108)\end{array}$ & $\begin{array}{l}0.057 \\
(0.373)\end{array}$ \\
\hline Condition & & & & & & $\begin{array}{l}1.000 \\
(0.000)\end{array}$ & $\begin{array}{l}0.378 \\
(0.001)\end{array}$ \\
\hline Fruit trees & & & & & & & $\begin{array}{l}1.000 \\
(0.000)\end{array}$ \\
\hline
\end{tabular}

Parameters included in the logistic regression analysis are in bold. The level of probability is given in brackets

\section{Discussion}

The study conducted in the agricultural landscape of SE Poland indicates a strong relationship between SW and several features of non-forest tree stands. For the occurrence of this species, the diversity of trees was significant, being substantially higher within breeding territories in comparison to areas unoccupied by the birds. It can be assumed that this feature has a positive effect on the availability of food for the woodpeckers, as tree stands characterized by greater species diversity usually have more resources and a greater variety of invertebrates (e.g. Sobek et al. 2009a, b; O'Brien et al. 2017), which constitute the main part of the SW's diet (Glutz von Blotzheim and Bauer 1980; Cramp 1985, Michalczuk and Michalczuk 2017). Another important factor that could increase the availability of food for woodpeckers in non-forest habitats was probably the greater number of trees recorded in the stands occupied by breeding pairs. It can be assumed that such woodlots with a larger biomass also have more invertebrate resources (e.g. 
Table 4 Set of possible models explaining the occurrence of the Syrian Woodpecker in the agricultural landscape (see Table 1 for the description of variables)

\begin{tabular}{|c|c|c|c|c|c|}
\hline Model & $k$ & AIC & $p$ & $\Delta \mathrm{AIC}$ & $w$ \\
\hline Diversity + condition & 2 & 344.663209 & 0.000157 & 0.00 & 0.400156 \\
\hline Diversity + condition + total trees & 3 & 346.211149 & 0.000445 & 1.55 & 0.184543 \\
\hline Diversity + condition + fruit trees & 3 & 346.573653 & 0.000529 & 1.91 & 0.153951 \\
\hline Diversity + total trees + condition + fruit trees & 4 & 348.030011 & 0.001150 & 3.37 & 0.074325 \\
\hline Total trees + condition & 2 & 349.520078 & 0.001777 & 4.86 & 0.035284 \\
\hline Diversity & 1 & 349.581126 & 0.001128 & 4.92 & 0.034223 \\
\hline Diversity + fruit trees & 2 & 349.903599 & 0.002152 & 5.24 & 0.029127 \\
\hline Total trees + condition + fruit trees & 3 & 350.301452 & 0.003066 & 5.64 & 0.023873 \\
\hline Diversity + total trees + fruit trees & 3 & 351.071890 & 0.004396 & 6.41 & 0.016241 \\
\hline Condition & 1 & 351.089762 & 0.002561 & 6.43 & 0.016096 \\
\hline Diversity + total trees & 2 & 351.161100 & 0.004036 & 6.50 & 0.015532 \\
\hline Condition + fruit trees & 2 & 352.137529 & 0.006576 & 7.47 & 0.009532 \\
\hline Total trees + fruit trees & 2 & 353.556278 & 0.013367 & 8.89 & 0.004689 \\
\hline Fruit trees & 1 & 355.963678 & 0.039891 & 11.30 & 0.001407 \\
\hline Total trees & 1 & 356.606893 & 0.058504 & 11.94 & 0.001020 \\
\hline
\end{tabular}

The number of variables $(k)$, Akaike information criterion (AIC), probability level $(p)$, difference between the model and the best performing model $(\triangle \mathrm{AIC})$ and AIC weight $(w)$ are given for each model. Models with $\Delta \mathrm{AIC}<2.0$ are in bold

Table 5 Results of model-averaged estimates

\begin{tabular}{llllr}
\hline Variables & RVI & E & SE & \multicolumn{1}{l}{$95 \%$ CI } \\
\hline Diversity & 0.91 & 0.44 & 0.46 & 0.12 to 0.85 \\
Condition & 0.90 & 0.37 & 0.22 & 0.10 to 0.71 \\
Total trees & 0.36 & 0.01 & 0.03 & -0.04 to 0.11 \\
Fruit trees & 0.31 & 0.00 & 0.00 & -0.01 to 0.01
\end{tabular}

$R V I$ relative variable importance, $E$ estimate, $S E$ standard error, 95\% CI lower and upper confidence intervals

Southwood et al. 1982; Campos et al. 2006; Neves et al. 2013), which in the end may improve the foraging conditions of woodpeckers in non-forest tree stands. The larger sized trees, whose greater trunk diameters in woodlots occupied by SW, might have improved the foraging potential of urban habitats (Figarski and Kajtoch 2018). However, the present study in the agricultural landscape of SE Poland has not confirmed these patterns, which can be explained by substantial differences between urban and agricultural landscapes (compare studies Ciach and Fröhlich 2013; Michalczuk and Michalczuk 2016b; Figarski and Kajtoch 2018).
Another factor determining the occurrence of SW in the agricultural landscape was an increased share of fruit trees in the stands inhabited by the species. Similar relationships were also found in the urban environment of central Poland (Figarski and Kajtoch 2018). With the woodpeckers commonly foraging on fruit, the presence of fruit trees in non-forest tree stands may considerably increase the food resources used by these birds (Glutz von Blotzheim and Bauer 1980; Cramp 1985). In particular, the fruits of walnut Juglans regia, wild and sweet cherry Prunus avium, $P$. cerasus. and plum trees Prunus sp., are an important component of the birds diet in autumn and winter (Stevanović 1960; Szlivka 1962; Winkler 1973). SW also feed their nestlings on plant food (Szlivka 1962; Winkler 1972; Mitjaj 1986; Michalczuk and Michalczuk 2017).

The presence of fruit trees in the habitats of the SW (especially noted in old-growth orchards) may also be important due to the poorer health condition of such trees compared to other non-fruit trees noted in the agricultural landscape (Michalczuk and Michalczuk 2016b). The presence of sick and dying or dead trees in the environment positively affects the presence of many invertebrates, including beetle larvae (e.g. 
Lachat et al. 2012; Normann et al. 2016), which can be important even for the opportunistic SW. This may be especially important in the first period of life of this species' nestlings, when beetle larvae constitute half of the food items brought by parents (Michalczuk and Michalczuk 2017). The wide use of fruit trees by SW may also be associated with the nesting preferences of this species, using trees in poorer health condition (Michalczuk and Michalczuk 2016b, 2020a). Many species of woodpeckers tend to excavate cavities in the weakest parts of trees-in trunks and branches that are often dying, dead or infected by fungi (Schepps et al. 1999; Kosiński et al. 2006; Kosiński and Kempa 2007). This is especially important for woodpeckers with weaker neck muscles, limiting their ability to excavate cavities in hard wood (Hågvar et al. 1990; Kosiński et al. 2006; Kosiński and Kempa 2007). This is a possible reason, for which SWs prefer old fruit trees for nesting in Europe (Szlivka 1957; Ruge 1969; Michalczuk and Michalczuk 2016b, 2020b) and Asia (Ar et al. 2004; Aghanajafizadeh et al. 2011).

\section{Conservation recommendations}

Even though the SW is the most ecologically flexible of European woodpeckers (Glutz von Blotzheim and Bauer 1980; Cramp 1985) and non-forest tree stands are widely available in the agricultural landscape (e.g. Michalczuk et al. 2018), the protection of this species may be difficult to implement in Europe. As research has shown, in order to maintain the habitats of the SW, anthropogenic environments must include stands with a large variety of species, also with a larger number of trees, and which are characterized by the presence of trees in poorer health condition. Health and safety policies tend to remove dead, dying or weakened trees from populated areas, depriving woodpeckers from their food resources. Similarly, intensification of agriculture leads to landscapes homogenization, in particular to the loss of the scattered wooded "fabric", typical for traditional rural landscapes (Bobiec et al. 2019). This species reacts negatively to the loss of such trees from anthropogenic tree stands, as can be seen in the case of the degradation of orchards (Michalczuk and Michalczuk 2015), which usually have trees in poor health and are therefore the main habitats of the SW (Szlivka 1957, 1962; Ruge 1969; Michalczuk and Michalczuk 2016b; Figarski and
Kajtoch 2018). The result of such adverse changes occurring in habitats is probably the decline in the number of SW recorded in recent years in the agricultural landscape, e.g. in SE Poland, where the species' population decreased by half (Michalczuk and Michalczuk 2006a; Michalczuk et al. 2011; Michalczuk and Michalczuk 2015; Michalczuk et al. 2018). Therefore, it is advisable that the most effective protection of the SW habitats could be secured by adequate agro-forestry systems, involving components traditional husbandry fostering tree groves, solitary veteran trees, savanna-like loose stands, and fruit high orchards (Bergmeier et al. 2010, Bobiec et al. 2019, and other papers cited there). However, this task may be difficult to implement, e.g. in orchards or gardens, due to their general location on private land (e.g. Michalczuk and Michalczuk 2015; Michalczuk et al. 2018). Nevertheless, an ecological restoration process of such habitats should be considered. This would make landscape more heterogeneous. Also, the restored areas would not be exposed to transformation if they were protected by local dwellers. That goal might be achieved through agroenvironmental schemes benefiting wood-pastures, old orchards and other important features of working traditional landscapes (e.g. Bergmeier et al. 2010, Fischer et al. 2012, Bobiec and Mázsa 2017, Bobiec et al. 2019). The protection of such habitats should, however, be strengthened within human settlements, because tree stands located among residential buildings constitute the fundamental area of the SW's occurrence in Europe (Michalczuk and Michalczuk 2016b, 2020b). Previous programs introduced, for example, in Poland to protect traditional orchards may be insufficient, and the problem is significant, as it concerns a species included in Annex I of the Wild Birds Directive (Directive 2009), which requires that European Union countries plan and implement its protection. The prospect of protecting and properly developing non-forest tree stands, taking into account the requirements of the SW, may also contribute to the effective protection of habitats of many rare and endangered species, such as insects e.g. Great Capricorn Beetle Cerambyx cerdo or Hermit Beetle Osmoderma eremita (Oleksa and Gawroński 2006; Oleksa et al. 2007, 2013; Albert et al. 2012; Horák 2017), which allows the SW to be treated as an umbrella species. Equally important is the fact that the SW, as the dominant primary cavity nester in non-forest tree 
stands (Michalczuk et al. 2018), also plays an important role as the main provider of nest sites for secondary cavity nesters in anthropogenic habitats e.g. for European Starling Sturnus vulgaris, Wryneck Jynx torquilla, Tree Sparrow Passer montanus or House Sparrow Passer domesticus (e.g. Szlivka 1957, 1962; Ruge 1969; Gorman 2004; Michalczuk and Michalczuk 2016b). Thus it can be considered a keystone species in synanthropic environments, which increases the biodiversity of tree stands in the agricultural landscape and should be effectively protected.

Acknowledgements I wish to thank Monika Michalczuk for assistance in collection of data. I am very grateful to Dr. Lech Zareba for his assistance in performing the statistical calculations and Prof. Andrzej Bobiec for comments to an earlier version of the manuscript.

Funding This research received no specific grant from any funding agency, commercial or not-for-profit sectors.

Data availability The datasets generated during and/or analysed during the current study are available from the corresponding author on reasonable request.

\section{Compliance with ethical standards}

Conflict of interest The author declares that he/she has no conflict of interest.

Ethical standards Not applicable.

Open Access This article is licensed under a Creative Commons Attribution 4.0 International License, which permits use, sharing, adaptation, distribution and reproduction in any medium or format, as long as you give appropriate credit to the original author(s) and the source, provide a link to the Creative Commons licence, and indicate if changes were made. The images or other third party material in this article are included in the article's Creative Commons licence, unless indicated otherwise in a credit line to the material. If material is not included in the article's Creative Commons licence and your intended use is not permitted by statutory regulation or exceeds the permitted use, you will need to obtain permission directly from the copyright holder. To view a copy of this licence, visit http://creativecommons.org/licenses/by/4.0/.

\section{References}

Aghanajafizadeh A, Heydari F, Naderi G, Hemami MR (2011) Nesting hole site selection by the Syrian Woodpecker, Dendrocopos syriacus, in Yazad province, Iran. Zool Middle East 53:3-6. https://doi.org/10.1080/09397140. 2011.10638494
Albert J, Platek M, Cizek L (2012) Vertical stratification and microhabitat selection by the Great Capricorn Beetle (Cerambyx cerdo) (Coleoptera: Cerambycidae) in opengrown, veteran oaks. Eur J Entomol 109:553-559

Ar A, Barnea A, Yom-Tov Y, Mersten-Katz C (2004) Woodpecker cavity aeration: a predictive model. Resp Physiol Neurobi 144:237-249. https://doi.org/10.1016/j.resp.2004. 04.019

Bański J (ed) (2010) Atlas Rolnictwa Polski. IGiPZ PAN, Warsaw

BDL (2016) Bank Danych o Lasach. http://www.bdl.lasy.gov. pl. Accessed 22 Nov 2016

Berg A (2002) Composition and diversity of bird communities in Swedish farmland-forest mosaic landscapes. Bird Study 49:153-165. https://doi.org/10.1080/00063650209461260

Bergmeier E, Petermann J, Schröder E (2010) Geobotanical survey of wood-pasture habitats in Europe: diversity, threats and conservation. Biodivers Conserv 19:2995-3014. https://doi.org/10.1007/s10531-010-98723

Bobiec A, Mázsa K (eds) (2017) Rzeszów-Eger resolution on traditional rural landscapes of the Carpathian region. Wooded Rural Landscapes in CE Europe: biodiversity, cultural legacy and conservation. In: International scientific conference 20-25 September 2017. Rzeszów-Eger

Bobiec A, Podlaski R, Ortyl B, Korol M, Havryliuk S, Öllerer K, Ziobro J, Pilch K, Dychkevych V, Dudek T, Mázsa K, Varga A, Angelstam P (2019) Top-down segregated policies undermine the maintenance of traditional wooded landscapes: evidence from oaks at the European Union's eastern border. Landsc Urb Plan 189:247-259. https://doi. org/10.1016/j.landurbplan.2019.04.026

Burnham KP, Anderson DR (2002) Model selection and multimodel inference: a practical information-theoretic approach. Springer, New York

Campos RI, Vasconcelos HL, Ribeiro SP, Neves FS, Soares JP (2006) Relationship between tree size and insect assemblages associated with Anadenanthera macrocarpa. Ecology 29:442-450

Ciach M, Fröhlich A (2013) Habitat preferences of the Syrian Woodpecker Dendrocopos syriacus in urban environments: an ambiguous effect of pollution. Bird Study 60:491-499. https://doi.org/10.1080/00063657.2013. 847899

Cramp S (1985) The birds of the Western Palearctic, vol IV. Oxford University Press, Oxford

Directive (2009) Directive 2009/147/EC of the European Parliament and of the Council of 30 November 2009 on the conservation of wild birds. Official Journal of the European Union, 26.01.2010. https://eur-lex.europa.eu/eli/dir/2009/ 147/oj. Accessed 22 Nov 2016

Domokos E, Domokos J (2016) Bird communities of different woody vegetation types from the Niraj Valley, Romania. Turk J Zool 40:734-742. https://doi.org/10.3906/zoo1510-64

Dorresteijn I, Nimmo DG, Loos J, Hanspach J, Moga CI, David A, Ernst LM, Fischer J (2018) A new world for old landscapes: land-use intensification and bird conservation in a traditional farming landscape. North West J Zool 14:199-207 
Figarski T, Kajtoch $Ł$ (2018) Differences in habitat requirements between two sister Dendrocopos woodpeckers in urban environments: implication for the conservation of Syrian Woodpecker. Acta Ornithol 53:23-36. https://doi. org/10.3161/00016454AO2018.53.1.003

Fischer J, Hartel T, Kuemmerle T (2012) Conservation policy in traditional farming landscapes. Conserv Lett 5:167-175. https://doi.org/10.1111/j.1755-263X.2012.00227.x

Glue DE, Boswell T (1994) Comparative nesting ecology of the three British breeding woodpeckers. Br Birds 87:253-269

Glutz von Blotzheim UN, Bauer K (1980) Handbuch der Vögel Mitteleuropas, vol 9. Akademische Verlag, Wiesbaden

Gorman G (2004) Woodpecker nest holes. Alula 3:122-125

Hågvar S, Hågvar G, Mønness E (1990) Nest site selection in Norwegian woodpeckers. Holarctic Ecol 13:156-165

Hebda G (2009) Nesting sites of the Great-spotted Woodpecker Dendrocopos major L. in Poland: analysis of nest cards. Pol J Ecol 57:149-158

Horák J (2017) Insect ecology and veteran trees. J Insect Conserv 21:1-5. https://doi.org/10.1007/s10841-017-9953-7

Hosmer DW, Lemeshow S (1989) Applied logistic regression. Wiley, New York

Hristov I, Petkov N (2013) State of common birds in Bulgaria 2005-2011. Bulgarian Society for the Protection of Birds. Conservation series. Book 26 BSPB, Sofia

Kajtoch $Ł$, Figarski T (2017) Comparative distribution of Syrian and great spotted woodpeckers in different landscapes of Poland. Folia Zool 66:29-36. https://doi.org/10.1163/ 1568539X-00003452

Kondracki J (2000) Geografia regionalna Polski. Wyd. Nauk. PWN, Warsaw

Kosiński Z, Kempa M (2007) Density, distribution and nestsites of woodpeckers Picidae, in a managed forest of Western Poland. Pol J Ecol 53:519-533

Kosiński Z, Ksit P, Winiecki A (2006) Nest site of great spotted woodpeckers Dendrocopos major and middle spotted woodpeckers Dendrocopos medius in near-natural and managed riverine forests. Acta Ornithol 41:21-32

Krebs CJ (2014) Ecological methodology, 3rd edn. Addison Wesley Longman, London

Lachat T, Wermelinger BW, Gossner M, Bussler H, Isacsson G, Müller J (2012) Saproxylic beetles as indicator species for dead-wood amount and temperature in European beech forests. Ecol Ind 23:323-331. https://doi.org/10.1016/j. ecolind.2012.04.013

Michalczuk J, Michalczuk M (2006a) Reaction on playback and density estimations of Syrian Woodpecker Dendrocopos syriacus in agricultural areas of SE Poland. Acta Ornithol 41:33-39

Michalczuk J, Michalczuk M (2006b) Przydatność metody kartograficznej z użyciem stymulacji głosowej do oceny liczebności dzięcioła białoszyjego Dendrocopos syriacus. Not Orn 47:175-184

Michalczuk J, Michalczuk M (2011) Dzięcioł białoszyi Dendrocopos syriacus w Zlewni Górnej Huczwy w latach 2004-2006. Chrońmy Przyr Ojcz 67:426-432

Michalczuk J, Michalczuk M (2015) Spadek liczebności dzięcioła białoszyjego Dendrocopos syriacus w krajobrazie rolniczym południowo-wschodniej Polski w latach 2004-2012. Ornis Polonica 56:67-75
Michalczuk J, Michalczuk M (2016a) Habitat preferences of Picidae woodpeckers in the agricultural landscape of SE Poland: is the Syrian Woodpecker Dendrocopos syriacus colonizing a vacant ecological niche? North West J Zool 12:14-21

Michalczuk J, Michalczuk M (2016b) Nesting preferences of Syrian Woodpeckers Dendrocopos syriacus in the agricultural landscape of SE Poland. Acta Ornithol 51:71-81. https://doi.org/10.3161/00016454AO2016.51.1.006

Michalczuk J, Michalczuk M (2016c) Syrian Woodpecker Dendrocopos syriacus and Great Spotted Woodpecker Dendrocopos major coexistence in non-forest tree stands of the agricultural landscape in SE Poland. Turk J Zool 40:743-748. https://doi.org/10.3906/zoo-1601-13

Michalczuk J, Michalczuk M (2017) Diet variability of Syrian Woodpecker Dendrocopos syriacus nestlings in the rural landscape of SE Poland. North West J Zool 13:278-284

Michalczuk J, Michalczuk M (2020a) Nesting requirements of the Syrian Woodpecker Dendrocopos syriacus (Hemprich and Ehrenberg, 1833) (Aves: Picidae) in the Rural Landscape of SE Poland. Acta Zool Bulg. Published online 24 January 2020. http://www.acta-zoologica-bulgarica.eu/ 002328

Michalczuk J, Michalczuk M (2020b) Nest-site selection of the Syrian Woodpecker (Dendrocopos syriacus) in the agricultural landscape of SE Poland. Acta Zool Acad Aci H 66:189-202. https://doi.org/10.17109/AZH.66.2.189.2020

Michalczuk J, Michalczuk M, Cymbała R (2011) Przydatność rożnych metod do monitoringu liczebności dzięcioła białoszyjego Dendrocopos syriacus. Ornis Polonica 52:280-287

Michalczuk J, Boruchalski D, Mazurek P, Mazurek M, Michalczuk M, Cymbała R (2018) Występowanie dzięciołów Picidae w krajobrazie rolniczym wschodniej Zamojszczyzny. Ornis Polonica 59:231-249

Mitjaj IS (1986) Sirijskij djatel v Pridneprovskoj lesostepi. Rzucenie ptic SSSR, ich ochrana i racionalnoe ispolzovanie. Akademija Nauk SSSR, Leningrad

Neves FS, Sperber CF, Campos RI, Soares JP, Ribeiro SP (2013) Contrasting effects of sampling scale on insect herbivores distribution in response to canopy structure. Rev Biol Trop 61:125-137

Normann C, Tscharntke T, Scherber C (2016) Interacting effects of forest stratum, edge and tree diversity on beetles. For Ecol Manag 361:421-431. https://doi.org/10.1016/j. foreco.2015.11.002

O’Brien MJ, Brezzi M, Schuldt A, Zhang JY, Ma K, Schmid B, Niklaus PA (2017) Tree diversity drives diversity of arthropod herbivores, but successional stage mediates detritivores. Ecol Evol 7:8753-8760. https://doi.org/10. 1002/ece3.3411

Oleksa A, Gawroński R (2006) Forest insects in an agricultural landscape-presence of old trees is more important than the existence of nearby forest. Ecol Quest 7:29-36

Oleksa A, Ulrich W, Gawroński R (2007) Host tree preferences of hermit beetles (Osmoderma eremita Scop., Coleoptera: Scarabaeidae) in a network of rural avenues in Poland. Pol J Ecol 55:315-323

Oleksa A, Gawroński R, Tofilski A (2013) Rural avenues as a refuge for feral honey bee population. J Insect Conserv 17:465-472. https://doi.org/10.1007/s10841-012-9528-6 
R Development Core Team (2020) The R project for statistical computing. The R Foundation for Statistical Computing, Vienna, Austria. http://www.R-project.org/

Ruge K (1969) Beobachtungen am Blutspecht Dendrocopos syriacus im Burgenland. Vogelwelt 90:201-223

Schepps J, Lohr S, Martin TE (1999) Does tree hardness influence nest-tree selection by primary cavity nesters? Auk 116:658-665

Sobek S, Goßner MM, Scherber C, Steffan-Dewenter I, Tscharntke T (2009a) Tree diversity drives abundance and spatiotemporal $\beta$-diversity of true bugs (Heteroptera). Ecol Entomol 34:772-782. https://doi.org/10.1111/j.13652311.2009.01132.x

Sobek S, Steffan-Dewenter I, Scherber C, Tscharntke T (2009b) Spatiotemporal changes of beetle communities across a tree diversity gradient. Divers Distrib 15:660-670. https:// doi.org/10.1111/j.1472-4642.2009.00570.x

Southwood TRE, Moran VC, Kennedy CEJ (1982) The richness, abundance and biomass of the arthropod communities on trees. J Anim Ecol 51:635-649

Spasov S, Hristov I, Eaton M, Nikolov SC (2017) Population trends of common birds in Bulgaria: is their status improving after the EU accession? Acta Zool Bulg 69:95-104

Spitznagel A (1990) The influence of forest management on woodpecker density and habitat use in floodplain forest of the Upper Rhine Valley. In: Carlson A, Aulén G (eds) Conservation and management of woodpecker populations. Swedish University of Agricultural Sciences, Department of Wildlife Ecology, Report 17, Uppsala, pp 117-145

Stevanović A (1960) Sezonska specijalizacija u ishrani djetla sirijskogo, Dendrocopos syriacus, okoline Kruševca (Župa). Larus XII-XIII:55-64

Szlivka L (1957) Von der Biologie des Blutspechts Dendrocopos syriacus balcanicus, und seinen Beziehungen zu den Staren, Sturnus vulgaris. Larus 9(10):48-70

Szlivka L (1962) Weitere Angaben über den Blutspecht aus der näheren Umgebung von Gunaroš. Larus 14:121-134

Winkler H (1972) Beitrege zur Ethologie des Blutspechts (Dendrocopos syriacus). Das nicht-reproduktive Verhalten. Z Tierpsychol 31:300-325

Winkler H (1973) Nahrungserwerb und Konkurrenz des Blutspechts Picoides (Dendrocopos) syriacus. Oecologia 12:193-208

Zieliński R (1972) Tablice statystyczne. Wyd. Nauk. PWN, Warsaw

Publisher's Note Springer Nature remains neutral with regard to jurisdictional claims in published maps and institutional affiliations. 